\title{
The relation of the isoagglutinins in pooled plasma to the haemolytic anaemia of burns
}

\author{
E. TOPLEY AND J. P. BULL, W. d'A. MAYCOCK, \\ A. E. MOURANT AND D. PARKIN \\ From the M.R.C. Industrial Injuries and Burns Research Unit, Birmingham, Lister Institute \\ of Preventive Medicine, Elstree, and M.R.C. Blood Group Reference Laboratory, \\ c/o Lister Institute of Preventive Medicine, London, S.W.I
}

SYNOPSIS Patients showing red cell loss following severe burns have been considered in two groups, the more severe cases with late haemoglobinuria and the more numerous less severe cases without late haemoglobinuria. Patients who had late haemoglobinuria usually belonged to group A or AB, showed a normal or increased osmotic fragility of red cells, and had received more than three plasma volumes of pooled plasma. It is suggested that this haemolytic anaemia may have been caused by the anti-A isoagglutinins in pooled plasma or serum. Patients showing red cell loss but who had no late haemoglobinuria had a normal ABO group distribution and an increased osmotic resistance of their red cells. It is concluded that this more common type of red cell loss in burns is independent of transfused isoagglutinins. Isoantibodies present in pooled plasma have been investigated. Corresponding antibodies have been demonstrated in the serum of groups $A$ and AB patients transfused with moderate quantities of pooled plasma. The same patients commonly also had a raised erythrocyte sedimentation rate, without there being a clinically important red cell loss.

The proportions of the groups of the bloods used in preparing dried pooled plasma are arranged to minimize the effects of isoagglutinins, and the resulting mixture can normally be safely infused without regard to the blood group of the recipient. There remains, however, the possibility that when such plasma is given in very large quantities sufficient isoagglutinins may be present to cause damage to the recipient's red cells. Such an occurrence has been reported by Keitel and Wich (1954) in patients receiving plasma transfusions, and other evidence has been reviewed by Mollison (1961). Large volumes of plasma are sometimes given in the treatment of burns, and Ebert and Emerson (1946) described increased osmotic fragility associated with transfusion of group $\mathrm{O}$ blood or plasma to seven patients, including one who developed haemoglobinuria and other signs of intravascular haemolysis and died.

In the present investigation the contribution of ABO isoagglutinins to red cell loss has been studied in a large series of burned patients treated with various plasma preparations, in many of whom red cell loss was measured by serial ${ }^{51} \mathrm{Cr}$ red cell volumes.

Received for publication 21 August 1962.

\section{CLINICAL MATERIAL}

Studies were made on 111 patients who received intravenous therapy for burns. The different régimes of treatment were: 1 Reconstituted dried pooled plasma given in amounts sufficient to maintain near normal circulatory volume (75 patients); 2 , comparison in a formal trial of six patients treated with plasma of homologous $\mathrm{ABO}$ group and four comparable cases treated with dried pooled plasma; 3 , comparison in another trial of a total of 26 patients treated with albumin, dried pooled serum, dried pooled plasma, or a combination of these.

Each pool of dried plasma or serum was derived from 10 donations of blood (four group $\mathrm{O}$, four group $\mathrm{A}$, two $B$ or $A B$, or one $B$ and one $A B$ ). Each bottle contained the dried solids from $400 \mathrm{ml}$. of acid-citratedextrose plasma or serum which were reconstituted with $400 \mathrm{ml}$. sterile distilled water. Each pool of homologous ABO group plasma was derived from 10 donations of blood.

\section{INVESTIGATIONS}

Red cell loss was calculated from ${ }^{51} \mathrm{Cr}$ or ${ }^{32} \mathrm{P}$ red cell volume measurements (Davies, 1960) and the average normal red cell volume for the patient's height and weight with suitable correction for volume of blood transfused 
(Topley and Jackson, 1957). These determinations were made when possible about six hours after injury (range two to eight hours) and thereafter daily for two or three days. The red cell loss was expressed as a percentage of the normal circulating red cell volume.

Hourly urine samples were examined for haemoglobin during the period of colloid transfusion. The term 'late haemoglobinuria' was used for the occurrence of at least three haemoglobin-stained hourly specimens between 12 and 48 hours after injury. This should be distinguished from an earlier haemoglobinuria probably due to the direct effect of heat on red cells.

Serological studies to detect anti-A isoagglutinins were made on the patients in the trial of homologous plasma and on certain others.

Osmotic fragility, erythrocyte sedimentation rate, and plasma protein studies were made on patients in the trial of albumin, dried pooled serum, and dried pooled plasma.

Osmotic fragility was measured by adding $0.05 \mathrm{ml}$. quantities of heparinized blood to $5 \mathrm{ml}$. quantities of a range of concentrations of sodium chloride. The latter were prepared from a stock solution checked by titration with silver nitrate. After keeping the suspensions of red cells at room temperature for two hours they were centrifuged and the optical density of the supernatant read on a Spekker photoelectric colorimeter using a blue-green filter (Ilford 625). These optical densities were expressed as percentages of that of a total lysate in ammonia-water of an equivalent quantity of red cells.

The erythrocyte sedimentation rate (E.S.R.) was measured by the method of Hardwicke and Squire (1952). Results were expressed both as distance of sedimentation in one hour and as maximum sedimentation velocity. The sedimentation rates of the patient's and normal cells in normal and patient's serum and plasma were also investigated. Fibrogen was determined by micro-Kjeldahl estimation on clots separated from oxalated plasma.

\section{RESULTS}

Severe red cell loss was found in a few patients and the evidence suggests that therapy with dried pooled plasma was partly responsible for this loss. These cases will be considered first.

SEVERE RED CELL LOSS A loss of more than $40 \%$ of red cells was found in 10 patients. All had late haemoglobinuria and two developed jaundice (Table I). Nine of these 10 patients died as compared with an expectation of 7.5 based on area of burn and age (Bull and Fisher, 1954). Eight other patients had late haemoglobinuria. In many instances it was associated with a smaller but still serious (20 to $40 \%$ ) loss of red cells; in a few cases the measurements of loss are inadequate to give a valid estimate of its degree.

Relation to $A B O$ groups Nine of the 10 most $\vec{\sigma}$ severe cases belonged to group $A$ or $A B$. When cases showing milder degrees of red cell loss were $\underset{ }{ }$ included as well as other cases with late haemoglobinuria, there were 13 instances of red cell loss known to have been greater than $20 \%$ in one day and 18 instances of late haemoglobinuria. These abnormalities occurred in 24 patients (Table II) ले only five of whom belonged to group $\mathbf{O}$ as against the 11 or 12 to be expected in a random sample of $\vec{c}$ the population. This difference is statistically $\omega$ significant $\left(\chi^{2}=6.8, P<0.01\right)$.

Osmotic fragility The osmotic fragility curves of seven group A patients with late haemoglobinuria showed either near normal or decreased resistance to saline (Fig. 1). This may be compared with 31 patients selected for similarity in burn area and the absence of late haemoglobinuria. The red cells of these 31 cases often showed increased resistance to saline (Fig. 2). Five of the seven patients with late haemoglobinuria showed $50 \%$ haemolysis of cells in $0.45 \%$ or higher saline concentration whereas only one out of 31 comparable cases without late haemoglobinuria had this degree of osmotic fragility.

TABLE I

DETAILS OF 10 PATIENTS WITH LATE HAEMOGLOBINURIA AND LOSS OF MORE THAN $40 \%$ OF RED CELL VOLUME MEASURED WITH ${ }^{51}$ CR TWO TO THREE DAYS AFTER THE BURN

\begin{tabular}{|c|c|c|c|c|c|c|c|c|c|}
\hline \multirow[t]{2}{*}{ Year } & \multirow{2}{*}{$\begin{array}{l}\text { Case } \\
\text { No. }\end{array}$} & \multirow[t]{2}{*}{ Age } & \multirow{2}{*}{ Group } & \multicolumn{2}{|c|}{ Area of Burn (\%) } & \multirow{2}{*}{$\begin{array}{l}\text { Plasma Volumes } \\
\text { of Dried, Pooled } \\
\text { Plasma, or Serum } \\
\text { by } 48 \text { Hours }\end{array}$} & \multirow{2}{*}{$\begin{array}{l}\text { Hours of } \\
\text { Haemoglobinuria }\end{array}$} & \multicolumn{2}{|c|}{$\begin{array}{l}\text { Maximum Recorded } \\
\text { Red Cell Disappearance }\end{array}$} \\
\hline & & & & Total & $\begin{array}{l}\text { Full-thickness } \\
\text { Loss }\end{array}$ & & & $\%$ & $\begin{array}{l}\text { Hours } \\
\text { after Burn }\end{array}$ \\
\hline
\end{tabular}

\begin{tabular}{|c|c|c|c|c|c|c|c|c|c|}
\hline $\begin{array}{l}1954 \\
1955 \\
1955 \\
1956 \\
1958 \\
1958 \\
1958 \\
1959 \\
1959 \\
1960\end{array}$ & $\begin{array}{l}11 \\
12 \\
13 \\
14 \\
15 \\
16 \\
17 \\
18 \\
19 \\
20\end{array}$ & $\begin{array}{r}4 \\
5 \\
10 \\
2 \\
11 \\
7 \\
7 \\
4 \\
50 \\
15\end{array}$ & $\begin{array}{l}\mathbf{A} \\
\mathbf{O} \\
\mathbf{A} \\
\mathbf{A} \\
\mathbf{A B} \\
\mathbf{A} \\
\mathbf{A} \\
\mathbf{A} \\
\mathbf{A} \\
\mathbf{A}\end{array}$ & $\begin{array}{l}70 \\
80 \\
85 \\
35 \\
65 \\
65 \\
65 \\
41 \\
40 \\
65\end{array}$ & $\begin{array}{l}70 \\
70 \\
80 \\
10 \\
25 \\
60 \\
60 \\
25 \\
38 \\
50\end{array}$ & $\begin{array}{r}7 \cdot 1 \mathrm{P} \\
9 \cdot 3 \mathrm{P} \\
11 \cdot 2 \mathrm{P} \\
5 \cdot 1 \mathrm{P} \\
7 \cdot 8 \mathrm{P} \\
3 \cdot 7^{1} \\
6 \cdot 6^{1} \\
6 \cdot 3 \mathrm{~S} \\
2 \cdot 8^{8} \\
5 \cdot 5^{1}\end{array}$ & $\begin{array}{c}31-48 \\
27-48 \\
0-48 \\
24-72 \\
23-36 \\
18-26 \\
0-30 \\
11-48 \\
\text { Anuric } \\
13-36\end{array}$ & $\begin{array}{r}65 \\
76 \\
63 \\
104 \\
49 \\
67 \\
43 \\
45 \\
46 \\
60\end{array}$ & $\begin{array}{l}36 \\
51 \\
48 \\
67 \\
49 \\
47 \\
31 \\
26 \\
26 \\
50\end{array}$ \\
\hline
\end{tabular}

Albumin replaced dried pooled plasma after haemoglobinuria had started. $\quad \mathbf{P}=$ Plasma only $\mathbf{8}=$ Serum only 


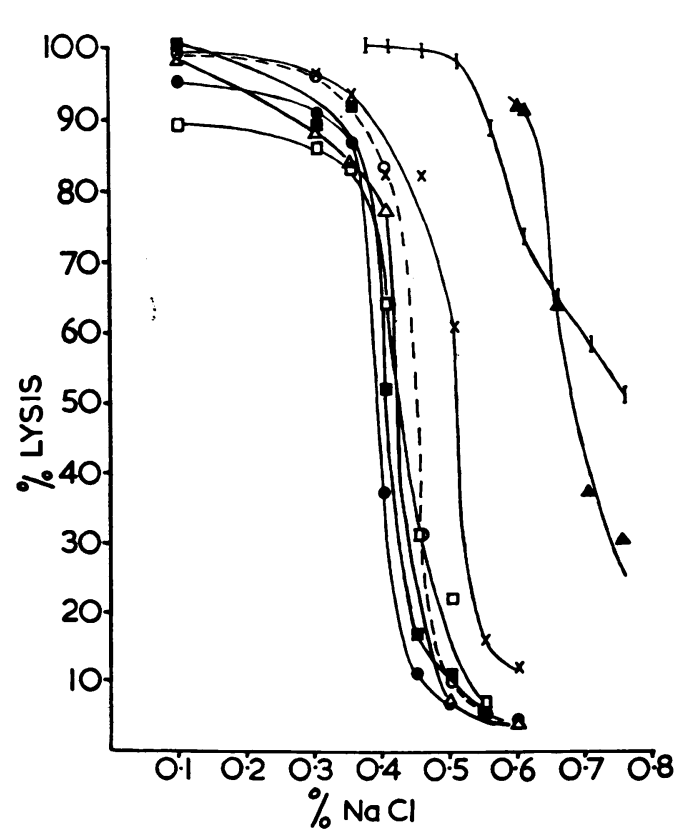

FIG. 1. Osmotic fragility curves of red cells 24 to 48 hours after injury in seven patients with late haemoglobinuria. $\bigcirc---\bigcirc=$ average result on normal individuals.

Serology Serological studies were made on six patients who had late haemoglobinuria. One of the two who also had jaundice (No. 15) was investigated in greater detail. Spherocytes were seen in the blood film, and saline resistance of red cells was markedly reduced (Fig. 1), and the blood appeared to 'agglutinate' in the syringe during sampling. Serum taken two days after the burn, at the time when jaundice was developing, was titrated in AB serum. It agglutinated $A$ cells to a dilution of $1: 8, B$ cells to $1: 8$, and $O$ cells to $1: 2$. After neutralization with secretor saliva there was still weak agglutination of A and B cells, though the indirect anti-globulin test using corresponding A or B cells was negative. No anti-A or anti-B was demonstrated in the eluate

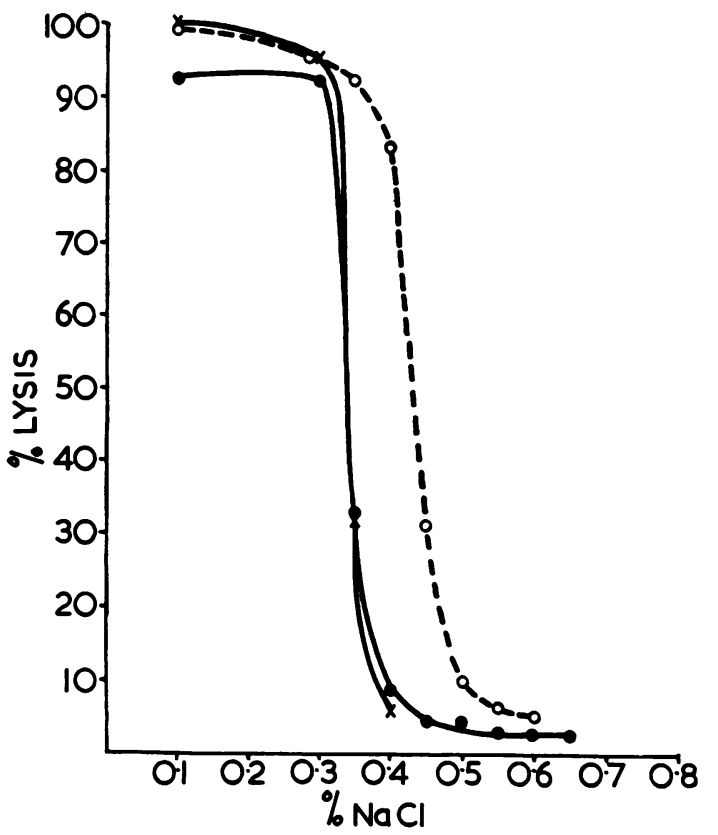

FIG. 2. Saline fragility curve of red cells 24 hours after injury in two patients without late haemoglobinuria. $\bigcirc---\bigcirc=$ average result on normal individuals.

prepared from the patients' red cells by heating aliquots in $\mathrm{AB}$ serum at $56^{\circ} \mathrm{C}$. for five minutes. The serum after storage was tested against a wide range of $\mathrm{O}$ cells, in saline and albumin at $37^{\circ} \mathrm{C} ., 20^{\circ} \mathrm{C}$., and $4^{\circ} \mathrm{C}$., and with cysteine-activated papain at $37^{\circ} \mathrm{C}$. but no agglutination was found.

The serum of three patients with late haemoglobinuria but without jaundice did not agglutinate saline suspensions of untreated or papainized $O$, $\mathrm{A}_{1}$, or $\mathrm{A}_{2}$ cells at $37^{\circ} \mathrm{C}$., $22^{\circ} \mathrm{C}$., or $4^{\circ} \mathrm{C}$. The serum of one patient with late haemoglobinuria was examined for the presence of haemolysins at $32^{\circ} \mathrm{C}$. and the results compared with those of normal serum. These tests with and without complement, using patients' and normal cells, failed to show any haemolysis.

TABLE II

PATIENTS SHOWING SOME EVIDENCE OF EXCESSIVE RED CELL DISAPPEARANCE (1954 TO 1960)

\begin{tabular}{|c|c|c|c|c|c|c|c|}
\hline \multirow[t]{2}{*}{ Evidence of Excessive Red Cell Disappearance } & \multirow{2}{*}{$\begin{array}{l}\text { Day after } \\
\text { Burn }\end{array}$} & \multicolumn{6}{|c|}{ Blood Group } \\
\hline & & $A$ & $\boldsymbol{B}$ & $A B$ & $\begin{array}{l}A, B, \\
\text { or } A B\end{array}$ & $O$ & Total \\
\hline Loss of more than $20 \%$ of red cell volume $\left({ }^{51} \mathrm{Cr}\right)$ & $\begin{array}{l}0-1 \\
1-2\end{array}$ & $\begin{array}{l}4 \\
4\end{array}$ & $\begin{array}{l}0 \\
1\end{array}$ & $\begin{array}{l}0 \\
1\end{array}$ & $\begin{array}{l}4 \\
6\end{array}$ & $\begin{array}{l}1 \\
2\end{array}$ & $\begin{array}{l}5 \\
8\end{array}$ \\
\hline Haemoglobin in at least three urine specimens & $\frac{1}{2}-2$ & 12 & 1 & 1 & 14 & 4 & 18 \\
\hline $\begin{array}{l}\text { Patients showing one or more of these findings } \\
\text { Expected from normal ABO distribution }\end{array}$ & & 16 & 2 & 1 & 19 & $\begin{array}{c}5 \\
11 \cdot 4\end{array}$ & $\begin{array}{l}24 \\
x^{2}=6.8 \\
P<0.01\end{array}$ \\
\hline
\end{tabular}


significantly different from the average for group A patients whether measured two to eight hours, one day, or two days after injury. This remains true if the cases are subdivided according to severity of burn or other feature which might be relevant.

In the controlled trial of homologous and pooled plasma, the six cases treated with homologous plasma and the four patients receiving dried pooled plasma in the same trial (Table IV) showed no significant difference of red cell loss, nor were the losses different from average findings after the administration of dried pooled plasma (Topley, Jackson, Cason, and Davies, 1962).

None of the sera of the six patients receiving homologous plasma contained any abnormal anti-A or anti-B isoagglutinins during transfusion. In the period of five to 45 hours after injury the serum of one of the four patients receiving pooled plasma (case 1) who was of group A showed traces of agglutination of $A$ cells when the serum was diluted with $\mathrm{AB}$ serum (Table $\mathrm{V}$ ). The direct antihuman globulin test was weakly positive and two red cell eluates showed a trace of anti-A activity by the indirect antihuman globulin test. The anti-A level remained virtually unchanged, but one eluate showed a trace of anti-B activity by the indirect antihuman globulin test. The results suggest that small traces of isoantibodies may be demonstrable following large transfusions of pooled dried plasma even when there is no late haemoglobinuria. It is moreover of interest that there was in this case an unusual loss of red cells around this time.

Direct and indirect antihuman globulin tests were made on a further 12 patients and agglutination

TABLE IV

DETAILS OF PATIENTS IN TRIAL, COMPARING RESULTS OF TRANSFUSION OF RECONSTITUTED DRIED HOMOLOGOUS PLASMA WITH THOSE OF TRANSFUSION OF RECONSTITUTED DRIED SMALL POOL PLASMA

\begin{tabular}{|c|c|c|c|c|c|c|c|c|c|c|}
\hline \multirow[b]{2}{*}{ Case No. } & \multicolumn{4}{|c|}{ Pooled Plasma } & \multicolumn{6}{|c|}{ Homologous Plasma } \\
\hline & 1 & 2 & 3 & 4 & 5 & 6 & 7 & 8 & 9 & 10 \\
\hline $\begin{array}{l}\text { ABO blood group } \\
\text { Age (years) }\end{array}$ & $\begin{array}{l}A \\
62\end{array}$ & $\begin{array}{l}A \\
65\end{array}$ & $\begin{array}{l}0 \\
70\end{array}$ & $\begin{array}{l}0 \\
60\end{array}$ & $\begin{array}{l}\text { A } \\
36\end{array}$ & $\begin{array}{l}A \\
45\end{array}$ & $\begin{array}{l}0 \\
6\end{array}$ & $\begin{array}{l}0 \\
74\end{array}$ & $\begin{array}{l}\text { B } \\
54\end{array}$ & $\begin{array}{l}B \\
6\end{array}$ \\
\hline $\begin{array}{l}\text { Area of burn ( } \% \text { total body area) } \\
\text { Total burn } \\
\text { Full-thickness loss }\end{array}$ & $\begin{array}{l}40 \\
30\end{array}$ & $\begin{array}{l}40 \\
35\end{array}$ & $\begin{array}{l}35 \\
30\end{array}$ & $\begin{array}{l}30 \\
20\end{array}$ & $\begin{array}{l}55 \\
50\end{array}$ & $\begin{array}{l}80 \\
30\end{array}$ & $\begin{array}{r}15 \\
7\end{array}$ & $\begin{array}{l}18 \\
12\end{array}$ & $\begin{array}{l}45 \\
30\end{array}$ & $\begin{array}{l}30 \\
20\end{array}$ \\
\hline $\begin{array}{l}\text { Microcytes on admission blood film (\%) } \\
\text { Plasma transfused in } 48 \text { hours (litres) } \\
\text { Normal plasma volume } \text { (litres) }^{1} \\
\text { Haemoglobinuria } 12 \text { to } 48 \mathrm{hr} \text {. }\end{array}$ & $\begin{array}{l}7 \\
8 \cdot 3 \\
3 \cdot 0 \\
2 \cdot 8 \\
-\end{array}$ & $\begin{array}{c}20 \\
3 \cdot 9 \\
1 \cdot 5 \\
2 \cdot 6 \\
-\end{array}$ & $\begin{array}{l}5 \\
4 \cdot 0 \\
2 \cdot 6 \\
1 \cdot 5 \\
-\end{array}$ & $\begin{array}{l}13 \\
3 \cdot 8 \\
2 \cdot 3 \\
1 \cdot 8 \\
-\end{array}$ & $\begin{array}{l}3 \\
13 \cdot 5 \\
2 \cdot 4 \\
5 \cdot 6 \\
-\end{array}$ & $\begin{array}{c}<2 \\
9 \cdot 7 \\
1 \cdot 8 \\
5 \cdot 4 \\
+2\end{array}$ & $\begin{array}{r}18 \\
1 \cdot 4 \\
0 \cdot 8 \\
1 \cdot 8 \\
-\end{array}$ & $\begin{array}{l}5 \\
2 \cdot 7 \\
1 \cdot 7 \\
1 \cdot 6 \\
-\end{array}$ & $\begin{array}{l}4 \cdot 8 \\
2 \cdot 3 \\
2 \cdot 1 \\
-\end{array}$ & $\begin{array}{l}2 \\
3 \cdot 1 \\
0 \cdot 8 \\
3 \cdot 9 \\
-\end{array}$ \\
\hline $\begin{array}{l}\text { Red cell disappearance }(\% \text { of normal red cell volume })^{1} \\
\text { By } 5 \text { to } 8 \text { hours } \\
\text { By day } 1 \\
\text { By day } 2 \\
\text { By day } 3,4 \text {, or } 5\end{array}$ & $\begin{array}{r}7 \\
6 \\
19 \\
21\end{array}$ & $\underset{5}{\text { Gain } 17}$ & $\begin{array}{r}6 \\
8 \\
20\end{array}$ & $\begin{array}{l}\text { Gain } 3 \\
21 \\
\text { Gain } 9\end{array}$ & $\begin{array}{l}13 \\
29 \\
25\end{array}$ & $\begin{array}{l}17 \\
31\end{array}$ & $\begin{array}{l}\text { Gain } 2 \\
\text { Gain } 4\end{array}$ & $\begin{array}{l}13 \\
22\end{array}$ & $\begin{array}{l}55 \\
68\end{array}$ & $\begin{array}{l}\text { Gain } 6 \\
\text { Gain } 5\end{array}$ \\
\hline$\cdot$ More than $20 \%$ in one day & - & + & - & + & - & - & - & - & + & + \\
\hline
\end{tabular}

${ }^{1}$ Taken from average normal figures for height (Topley and Jackson, 1957) except in short adults. (In case 3 weight was used and in case 8 weight and height were used.)

'Two different urine specimens only

TABLE V

FINDINGS IN CASE 1 AFTER 8.3 LITRES OF DRIED POOLED PLASMA (NORMAL PLASMA VOLUME FOR HEIGHT 3.0 LITRES)

Time after Burn

\begin{tabular}{|c|c|c|c|c|c|c|}
\hline & \multicolumn{6}{|c|}{ Time after Burn } \\
\hline & I Hour & 5 Hours & 18 Hours & 45 Hours & 56 Hours & 3 Days \\
\hline $\begin{array}{r}\text { Plasma transfused (litres) } \\
\text { Plasma volumes }\end{array}$ & $\begin{array}{l}\mathbf{0} \\
\mathbf{0}\end{array}$ & $\begin{array}{l}3 \cdot 0 \\
1\end{array}$ & $\begin{array}{l}6 \cdot 0 \\
2\end{array}$ & $\begin{array}{l}7 \cdot 4 \\
2 \cdot 5\end{array}$ & $\begin{array}{l}8 \cdot 3 \\
2 \cdot 8\end{array}$ & \\
\hline $\begin{array}{l}\text { Anti-B titre in saline } \\
\text { In AB serum }\end{array}$ & $\begin{array}{l}32 \\
32\end{array}$ & $\begin{array}{l}16 \\
16\end{array}$ & $\begin{array}{l}16 \\
32\end{array}$ & $\begin{array}{r}8 \\
16\end{array}$ & $\begin{array}{r}8 \\
32\end{array}$ & $\begin{array}{r}8 \\
16\end{array}$ \\
\hline $\begin{array}{l}\text { Anti-A titre in saline } \\
\text { In } \mathbf{A B} \text { serum }\end{array}$ & $\begin{array}{l}\mathbf{0} \\
\mathbf{0}\end{array}$ & $\begin{array}{l}0 \\
\text { Trace }\end{array}$ & $\begin{array}{l}0 \\
\text { Trace }\end{array}$ & $\begin{array}{c}0 \\
\text { Trace }\end{array}$ & $\begin{array}{l}\mathbf{0} \\
\mathbf{0}\end{array}$ & $\begin{array}{l}\mathbf{0} \\
\mathbf{0}\end{array}$ \\
\hline $\begin{array}{l}\text { Direct anti-human globulin test } \\
\text { Eluate, indirect anti-human globulin test } \\
\text { Total red cell disappearance by }{ }^{51} \mathrm{Cr} \text { estimation }\end{array}$ & $\begin{array}{l}0 \\
0\end{array}$ & $\begin{array}{l}\text { Weak } \\
\alpha \text { and } \beta \\
7 \%\end{array}$ & $\begin{array}{l}\text { Weak } \\
0 \\
6 \%\end{array}$ & $\begin{array}{l}\text { Weak } \\
\alpha \\
30 \%\end{array}$ & $\begin{array}{l}\mathbf{0} \\
\mathbf{0}\end{array}$ & $\begin{array}{l}\mathbf{0} \\
\mathbf{0} \\
32 \%\end{array}$ \\
\hline
\end{tabular}




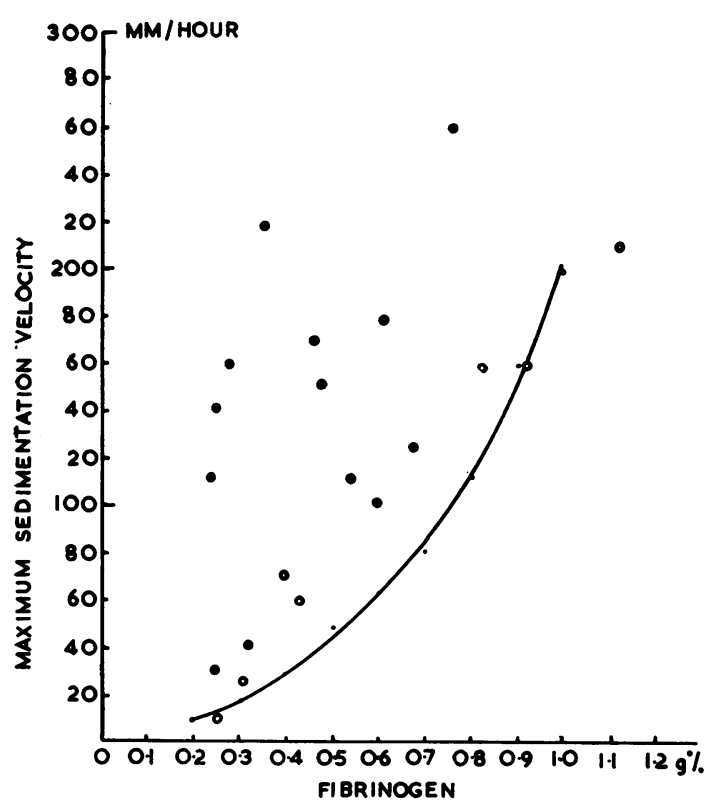

FIG. 4. Relationship between maximum erythrocyte velocity and fibrinogen level 24 to 48 hours after injury.

$\mathrm{O}=\operatorname{group} O$

$\boldsymbol{0}$ group $\boldsymbol{A}$

$\cdot=$ Results on artificial mixtures of fibrinogen

tests of saline suspensions of normal and trypsinized red cells on 30 patients at $37^{\circ} \mathrm{C}$. In each case the patient's serum and normal serum were tested against the patient's cells and normal cells of the same ABO group. Neither the red cells nor serum of the patients showed any significant abnormality and there was no difference between patients with less than average and those with more than average red cell disappearance.

Group A patients showed a higher erythrocyte sedimentation rate than group $O$ patients when tested 24 to 48 hours after injury. The relationship between the erythrocyte sedimentation rate and fibrinogen level at this time is shown for group $\mathrm{O}$ and group A patients (Fig. 4). Each point represents a different patient, the results nearest to 24 hours being selected for all patients with tests 24 to 48 hours after injury. Mixtures of fibrinogen in normal plasma were prepared and their fibrinogen content assayed by the same method as for the patient's plasma. The line shown in Fig. 4 represents the maximum erythrocyte sedimentation velocity for these mixtures. The group $O$ patients showed maximum sedimentation velocities only slightly greater than those expected for the fibrinogen level while the group A patients had higher sedimentation rates. This difference was therefore possibly due to some factor in the patient's serum. The role of serum factors was investigated in six patients by making mixtures of the patients' serum with normal plasma $\overrightarrow{\vec{s}}$ and red cells. The serum of the three group $\mathbf{O}$ cases contributed less to the sedimentation than that of $\frac{}{0}$ any of the three group A patients. One of these $\frac{\overline{\bar{c}}}{\text {. }}$ group A patients with a partial thickness skin loss $\widehat{\Phi}$ burn received $1 \cdot 1$ plasma volumes of dried pooled plasma. His serum markedly increased the erythro- ${ }^{\infty}$ cyte sedimentation rate when tested one, two, and $\vec{O}$ seven days after injury. The effect was absent on the $\vec{A}$ twenty-first day. He showed no red cell loss and now haemoglobinuria during the plasma transfusion.

The rise of fibrinogen level in 17 patients was. deliberately limited by transfusion of albumin or $\overline{ }$ serum instead of plasma, and the results compared $-\overrightarrow{-}$ with those from patients receiving pooled plasma. 6 In eight patients whose fibrinogen levels were low as을 a result of receiving albumin or serum transfusionmeasured red cell losses were not significantly@ reduced.

The $\gamma$ and $\alpha_{2}$ globulins, $\beta$ lipoprotein, and albumin were measured in 10 patients by gel diffusion. Therewas no apparent relation with the degree of red cello loss.

Haptoglobins were present in 10 or 11 patientso studied at various periods during the first 48 hours. O-toluidine staining was often present in the albumino and $\beta$ globulin as well as in the $\alpha_{2}$ globulin regions.

These findings in cases without late haemo- 0 globinuria demonstrate the increased erythrocyte sedimentation produced by the serum of group $\mathrm{A}^{3}$ patients receiving pooled plasma, and have failed to define any association between red cell loss and? abnormality of plasma proteins studied.

Blood cultures were taken during the shock stage in 25 patients without late haemoglobinuria. The blood of 11 of these patients showed some bacteraemia due to recognized pathogens during the first5 48 hours after injury. This bacteraemia was not significantly associated with any particular blood? group nor with the degree of measured red cell loss

ISOANTIBODIES IN POOLED DRIED PLASMA Sampleș of reconstituted dried pooled plasma were de- $N$ fibrinated. The anti-A and anti-B isoagglutinin titres were then measured in dilutions in saline or group ${ }_{O}^{\omega}$ AB serum (Table VI). In serum, titres of 1 in 16 to 1 in 32 were fairly common against group A cells: and slightly less common against group B cells $\$$ After neutralization with secretor saliva of the corresponding blood group, the serum agglutinations titre against group $\mathbf{A}$ cells fell, though antibodies? were still detectable (Tables VI and VII).

In saline, no titres of more than 1 in 64 agains $\stackrel{\mathbb{R}}{\Omega}$ group A or B cells were found (Table VI). 
TABLE VI

TITRES OF DRIED PLASMA POOLS

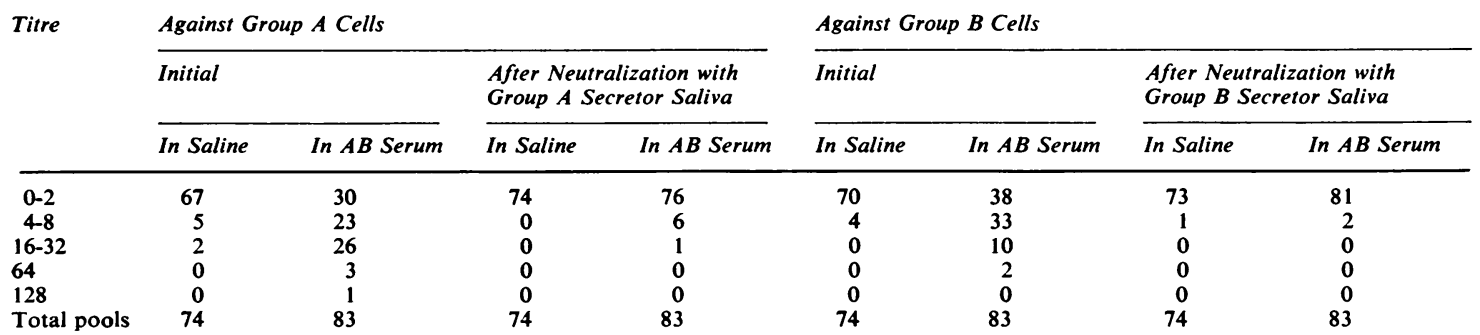

TABLE VII

INDIRECT ANTI-HUMAN GLOBULIN TESTS AFTER NEUTRALIZATION OF DRIED PLASMA POOLS WITH SECRETOR SALIVA OF CORRESPONDING GROUP

\begin{tabular}{lcc} 
Test & Group A Cells & Group B Cells \\
\hline Negative & 59 & 71 \\
Granular or weak & 6 & 2 \\
+ & 2 & 1 \\
++ or +++ & 7 & 0 \\
Total pools & 74 & 74
\end{tabular}

These titres are somewhat lower than those described by Ebert and Emerson (1946) for American dried pooled plasma.

\section{DISCUSSION}

The red cell loss following burns has been known and studied for many years (Sevitt, 1957). It is known that during the first day after injury some red cells are lost due to the direct effect of heat, while others are lost in the immediate area of the burn (Topley, 1962). Later red cell loss may be due to the local and sometimes systemic infection that is so often associated with large burns. Superimposed on these factors is the possible effect of anti-A isoagglutinins in the pooled plasma commonly transfused in the first two days to avoid serious oligaemia.

The present investigation was stimulated by the case of a patient (kindly brought to our attention by Dr. M. M. Pickles) who had developed a haemolytic anaemia following the transfusion of large volumes of reconstituted dried pooled plasma from 14 different pools. Of the eight pools available for examination, one pool had an $\alpha$ isoagglutinin titre (in $\mathrm{AB}$ serum) of 16 and altered the osmotic fragility of group $A$ but not of group B or group $O$ cells exposed to it. Group A cells exposed to this pool and then washed and resuspended in a range of concentrations of sodium chloride lysed completely in $0.7 \%$ saline.

Serial measurements of red cell volumes in burned patients combined with clinical observations have suggested that the loss in these patients can be conveniently considered as being of two types, one a severe haemolysis associated with 'late haemoglobinuria' and the other a less severe red cell loss without 'late haemoglobinuria' (Topley et al., 1962). The severe red cell loss associated with late haemoglobinuria occurs at a time (12 to 48 hours after injury) when the maximal effect of antibodies transfused in pooled plasma is likely to be attained. The present study shows a preponderance of A blood groups among the patients who suffered the excessive red cell loss (Tables I and II) and the blood of these patients showed a relative increase in osmotic fragility at the time of late haemoglobinuria. Ebert and Emerson (1946) showed by differential agglutination that the increase of osmotic fragility during the transfusion of group $\mathrm{O}$ blood to patients with burns affected the patients' group A cells, but not the donor group $O$ cells. Muir (1961) also noted increased osmotic fragility of red cells at the time of excessive red cell loss in two patients. These cases belonged to group $\mathrm{A}$. These findings are all consistent with the excessive red cell loss, often associated with haemoglobinuria 12 to 48 hours after a burn, being predominantly due to the anti-A transfused in dried pooled plasma.

In the second type of red cell loss, which is less severe, not associated with haemoglobinuria, and considerably more common than the first type, there is no suggestion that the amount of blood loss is greater in group $\mathrm{A}$ than in group $\mathrm{O}$ patients, and there is no associated relative increase in osmotic fragility. The red cell loss is therefore probably due to factors other than the anti-A in pooled plasma. Any blood loss due to isoantibodies is therefore small enough to be masked by this other blood loss. It must therefore be less than $20 \%$ of the circulating blood volume in most cases. Within these limits therefore the results on 79 burned patients suggest that transfusion of up to 2 to 3 plasma volumes of dried pooled plasma does not cause excessive loss of red cells.

We have also confirmed the observations of 
earlier workers that anti-A isoagglutinins are present in reconstituted dried pooled plasma (Table VI) and can sometimes be demonstrated in the blood of patients who have received plasma transfusion. The finding that among such patients, group A patients have a higher erythrocyte sedimentation rate than group $\mathrm{O}$ patients (Fig. 4) suggests that isoagglutinins may contribute to the sedimentation rate in vitro.

Other changes in severely burned patients which might cause red cell loss, such as raised erythrocyte sedimentation rate, raised fibrinogen or bacteraemia, cannot be the only cause, as excessive red cell loss has been found in patients transfused with serum instead of plasma, and also in patients with erythrocyte sedimentation rates no higher than those occurring in patients showing no red cell loss. The incidence of bacteraemia was the same in the cases with and without excessive loss of red cells.

The evidence therefore strongly suggests a haemolytic anaemia superimposed on other causes of red cell loss in some burned patients receiving more than 3 plasma volumes of dried pooled plasma. This effect might be reduced by excluding donors showing an appreciable amount of so-called 'immune' anti-A. The same end might be achieved by reducing plasma transfusion to the minimum required to avoid dangerous oligaemia, and by using other colloids in the rare cases where more than 2 or 3 plasma volumes of pooled plasma need to be given to a group $\mathrm{A}, \mathrm{B}$, or $\mathrm{AB}$ patient. Such alternatives include homologous plasma, albumin, and homologous. blood.

Our thanks are due to Dr. W. Weiner of the Birmingham Regional Blood Transfusion Service for preparing the pools of homologous plasma, to Drs. Soothill and? Stanworth of the Department of Experimental Pathology, University of Birmingham, for studies by immuno-s phoresis and ultracentrifuge, to Dr. John Davies for cooperation in the ${ }^{51} \mathrm{Cr}$ red cell volume studies, to $\mathrm{Dr}$ ? C. R. Ricketts for fibrinogen estimations, to Dr. S. $\overrightarrow{\vec{\omega}}$ Sevitt for the ABO grouping results on many patients, to Dr. E. J. L. Lowbury for bacteriology, Miss S. Baaro for help with osmotic fragility tests and electrophoresis,; and Mr. D. MacG. Jackson and his staff for closeas cooperation in the studies on burned patients; andespecially to Miss D. Connor and Miss C. M. Giles for $\widehat{\vartheta}$ their collaboration in the laboratory investigations.

\section{REFERENCES}

Bull, J. P., and Fisher, A. J. (1954). Ann. Surg., 139, 269.

Davies, J. W. L. (1960). J. clin. Path., 13, 105.

Ebert, R. V., and Emerson, C. P. (1946). J. clin. Invest., 25, 627.

Hardwicke, J., and Squire, J. R. (1952). Clin. Sci., 11, 333.

Keitel, H. G., and Wich, J. (1954). Amer. J. Dis. Child., 87, 537.

Mollison, P. L. (1961). Blood Transfusion in Clinical Medicine, $\omega$ p. 485. Blackwell, Oxford.

Muir, I. F. K. (1961). Brit. J. plast. Surg., 14, 273.

Sevitt, S. (1957). Burns: Pathology and Therapeutic Applications Butterworth, London.

Topley, E., and Jackson, D. MacG. (1957). J. clin. Path., 10, 1. (1962). To be published.

__, Jackson, D. MacG., Cason, J. S., and Davies, J. W. L. (1962) Ann. Surg., 155, 581 . 